\title{
FARMERS' PERCEPTIONS OF CLIMATE VARIABILITY, THEIR ADAPTATION STRATEGIES AND AGRICULTURAL PRODUCTIVITY: A CASE OF LIMPOPO PROVINCE, SOUTH AFRICA
}

\author{
Afful, D. B. ${ }^{1}$ and Ayisi, K. ${ }^{2}$ \\ Correspondence Author: D. B. Afful. Email: david.afful@ul.ac.za
}

\begin{abstract}
The provision of farm management decision support and advisory services to insure climate resilient agricultural production systems, especially for subsistence farmers, depends on data on such producers. The main objective of the paper was to generate such data by comparing the status quo regarding dryland, subsistence grain farmers' perceptions of climate variability, their adaptation strategies and crop productivity. Using a survey questionnaire, the comparison was made across time (2014 and 2017) in selected municipalities of Limpopo province. The findings across time and aggregated for all the different local municipalities investigated were similar regarding respondents' perceptions of climate variability, adaptation strategies used and crop productivity. The perceptions revealed that respondents were aware of the reality of climate variability and its negative effects on their crop and livestock production, Agricultural productivity amongst extension and non-extension recipients was low, with minimal differences. These findings auger well for the development of common strategies to improve the effectiveness of the support for farm management including climate variability that is provided by the public agricultural extension service to the group of producers in this study to reduce the negative effects of climate variability on their crop productivity. This will eventually help to improve their food security.
\end{abstract}

Keywords: Perceptions, Climate variability, Productivity, Spatial and temporal variation, Subsistence farming.

\section{INTRODUCTION}

Scientific evidence shows that there has been a warming of the global atmosphere over the past 1,500 years (Marcott Shakun, Clark, \& Mix, 2013). The evidence is found in rising temperatures, changes in rainfall cycles, resulting in droughts and flooding in some areas with concomitant increase in diseases and pests. These changing weather phenomena affect agricultural production and productivity (Clements, Haggar, Quezada \& Torres, 2011).

A large proportion of South Africa's agricultural production depends on climatic variables such as temperature and precipitation. The semi-arid nature of the country, coupled with its scarce ground water resources, make the agricultural sector vulnerable to climate change and variability. Furthermore, South Africa is a region that is very prone to severe drought and flood events and significant intra-seasonal variability during the core rainy season (DecemberFebruary) when farmers in the summer rainfall areas begin to plant (Reason, Hachigonta \&

\footnotetext{
${ }^{1}$ Professor, Centre for Rural Community Empowerment, School of Agricultural and Environmental Sciences. University of Limpopo, P/Bag X1106, Sovenga 0727. Tel. 015268 3847; Email david.afful@ul.ac.za, ORCID: 0000-0003-0973-6017

${ }^{2}$ Risk and Vulnerability Science Centre/VLIR-IUC Private Bag X1106, Sovenga, 0727, University of Limpopo, South Africa.
} 
Phaladi, 2005). Among the provinces in South Africa which have been predicted to be hardest hit by climate change and variability in terms of reduced crop production in 2080 are the NorthWest, Limpopo, Free State and Gauteng (Turpie \& Visser, 2012). Climate change and variability, therefore, have an influence on food security. Food insecurity is a problem in South Africa, especially for subsistence producers in rural areas (Food and Agricultural Organisation 2004; Altman, Hart \& Jacobs, 2009). Gregory, Ingram and Brklacich (2005) indicated that climate change and variability were among the most frequently cited drivers of food insecurity in southern Africa. The negative effects of climate change and variability can be very severe in places such as Limpopo Province, where 57\% of the population is engaged in crop production and only $25 \%$ of farmers irrigate. It is, therefore, not surprising that food insecurity among the population in this province has been estimated to be as high as 52\% (D' Haese, van Rooyen, Vink, \& Kirsten, 2011). The food insecurity situation in the Limpopo Province, indicated by the number of households who skipped a meal in 12 months before the survey in 2015 and 2016 worsened from 5,3\% in 2015 to 12,9\% in 2016 (Stats SA, 2016).

Agricultural producers in the Limpopo Province require effective production adaptation strategies in order to reduce their vulnerability (productivity and food security) to the devastating effects of climate change and variability. The government of South Africa, therefore, has tasked the public agricultural extension service to respond to the needs of small farmers in its Integrated Food Security programme (Department of Agriculture, 2002). Reports of a lack of public extension support for farmers (Khapayi \& Celliers, 2016) and extension personnel's limited knowledge about how to derive the benefits of locally available climate observational data however, appear pervasive and worrisome. Such problems have been reported in Zimbabwe (Mberego \& Sanga-Ngoie, 2014) and the Amazon (Brondizio \& Moran, 2008). This situation creates a deficiency in the dissemination of climate change and variability information and adaptation strategies to farmers. Agricultural producers, therefore, tend to rely on their perceptions, knowledge and skills to adapt to climate change and variability. In view of the positive relationship between perceptions and human behaviour (Arts, Frambachand \& Bijmott, 2011; Tornatzky \& Klein, 1982), it is necessary to study farmers' perceptions of climate change and variability. Their perceptions invariably affect their adaption strategies and, therefore, the agricultural productivity.

Even though many papers have been written on farmers' perceptions on climate variability and their adaptation measures (Roco, Engler, Bravo-Ureta \& Jara-Rojas, 2016; Hassan, \& Nhemachena, 2008; Egbe Yaro, Okon, \& Isong, 2014; Maponya, \& Mpandeli, 2012), they are generally a snap-shot in time and one location. According to Minae, Baker and Dixon (n.d), there is low quantity and low quality data in the public sector; this negatively influences evidence-based decision making. The generation, synthesis and comparison of data on subsistence dryland grain producers in different time periods and in different municipalities is thus warranted for better planning purposes. Effective extension support for subsistence producers within the current atmosphere of climate change and variability therefore, requires that extension policy makers and managers have data on farmer beneficiaries including their productivity, perceptions of climate variability and adaptation strategies across time and place. This will help improve the effectiveness of the extension effort and also farmers' productivity. Armed with this information, agricultural extension managers and field-level extension agents will be able to put in place decision support systems which are evidence-based to help the crop production of this group of farmers. This paper is, therefore needed in view of the fact that literature on the existence of such data based on our study methodology seems non-existent for this province. Our study thus fills an important knowledge gap. 
The purpose of the paper was to compare farmers' perceptions of climate variability, their adaptation strategies and agricultural productivity across time and in various municipalities of Limpopo Province. The following research questions and hypothesis were addressed to achieve the study purpose:

1. What are farmers' perceptions of climate variability phenomenon, their effects on crop and animal production and how do these perceptions differ across time and in various municipalities of Limpopo Province?

2. How does farmers' crop productivity differ across time and in various municipalities of Limpopo Province?

3. Subsistence dryland farmers' grain productivity does not differ across time and in various municipalities of Limpopo Province.

\subsection{CONCEPTUAL FRAMEWORK FOR ASSESSING VULNERABILITY}

Emerging conceptualisations of climate change and variability vulnerability analysis consider the properties of human-environmental systems that enable the system to cope and thereby link vulnerability with capacity of the system to adapt to the hazard. This approach of viewing vulnerability has been called 'social vulnerability' (Vincent \& Cull, 2010). The focus of this approach to studying vulnerability is on the socio-economic drivers such as poverty, and access to resources that are under the direct influence of humans. This makes such types of studies more relevant to policy makers and researchers as opposed to the bio-physical drivers of climate change and variability, which are not easy to influence. An integrated approach to vulnerability assessment, however, combines both views; social vulnerability (adaptive capacity) and bio-physical vulnerability (exposure and sensitivity) (Nelson, Kokic, Crimp, Martin, Meinke, Howden, Voil \& Nidumolu, 2010b; Gbetibouo \& Ringler, 2009).

In view of the long-term and continuous nature of change associated with climate change as opposed to the annual or seasonal fluctuations characteristic of climate variability and the short period of recall of weather events (10 years) by respondents, the analysis in this study of farmers' adaptation strategies was done with respect to climate variability.

Following Nelson et al. (2010b), this study used the Sustainable Rural Livelihoods framework (Department for International Development, 1999) as the conceptual framework to analyse the adaptive capacity and sensitivity of farming households to climate variability and extreme weather conditions. The vulnerability of subsistence crop farmers' food production system to climate variability can, therefore, be conceptualized in terms of their sensitivity, exposure and adaptive capacity. The adaptive capacity of farmers to climate change and variability in this study was investigated in terms of resources such as extension support. Farmers' sensitivity, however, was investigated by assessing the losses they suffered as perceived by them.

The phrase 'climate change and variability' was used throughout in the study but 'climate variability' was the focus for analysing respondents' adaptation capacity and sensitivity. 


\section{METHODOLOGY}

The data for this present paper was taken from 'Rounds 1 and 2' of the study, 'Climate variability and subsistence crop farmers' food security in Limpopo Province of South Africa: the role of public extension' (Afful, Ayisi, Kyei, Zwane, \& Oluwatayo, 2014 Unpublished; Afful and Ayisi, 2017) (Unpublished). The aim of the climate variability study in different locations of the province was to generate data on the status quo among others, subsistence dryland, grain farmers' productivity, their perceptions of climate variability, effects of their perceptions on their production, their adaption strategies and perceptions of the public extension information received. The data were collected from adult household members engaged in maize production by means personal interview schedules in 2014 and 2017 in different local municipalities of three district municipalities.

In the 2014 study (Round 1), two districts municipalities, Capricorn and Sekhukhune were purposively chosen for the study because each had a local municipality that was either prone to drought (Blouberg) or had undergone a government food security programme, Fetsa Tlala (Makhuduthamaga) respectively. Two other local municipalities investigated in the Capricorn and Sekhukhune districts were Aganang and Fetakgomo respectively. These two local municipalities were selected by simple random processes; Aganang from five municipalities and Fetakgomo from four. Five villages were then selected per local municipality by a simple random procedure. However, because of the difficulty of identifying households that received public extension in the last five years prior to the study and those that did not, but which needed to be included in the study, the researchers and Limpopo Department of Agriculture and Rural Development officials decided to randomly select 10 crop farmers from a list of farmers per village. A total of 200 crop farming households were selected for interviews. However, the final number interviewed for the study was 194 due to logistical challenges.

The 2017 study (Round 2) however, used a census approach in which all project members in 12 randomly selected villages in four local municipalities of Mopani district municipality (1. Giyani: 2 villages; 2. Tzaneen: 3 villages; 3. Phalaborwa: 3 villages; 4 . Maruleng: 4 villages) were included in the study. The sampling unit for the interviews was the adult household member who engaged in maize production. A total of 322 respondents were interviewed.

The study used a household's adaptive capacity to assess the influence of public extension on the household's crop production and therefore, its contribution to the household's food security in light of climate variability. Following Daze, Ambrose, and Ehrhart (2009), the impacts of climate-related factors such as loss of human life, damage to crops and death of livestock were taken as the sensitivity indicators.

The data were analysed using the Statistical Package for the Social Sciences (SPSS). Data organisation was by means of tables and charts and the analysis techniques used include descriptive statistics (percentages, means, median) and a t-test for inferential analysis. The descriptive statistics were used to describe aggregated information on respondents from the various locations surveyed based on the study variables (perceptions of climate variability, climate variability adaptation strategies and crop yields) for the different time periods of the study. An independent samples t-test was conducted to test the study hypothesis to compare the statistical significance of aggregated crop yields for respondents (recipients and nonrecipients of public extension farm management information including climate variability) from the various areas investigated across time. The Levene's test of homogeneity of variance 
was applied to the t-test to find out whether the null hypothesis of no variance in standard deviations in the two populations of subsistence maize farmers who received extension support and non-extension support recipients was not violated.

\section{RESULTS AND DISCUSSION}

\subsection{Perceptions of climate variability}

\subsubsection{Number of climate variability-related occurrences experienced by respondents}

Respondents were asked to quantify the number of their experiences of the climate variabilityrelated stimuli (Table 1) across the two different time periods (2003-2013) and 2006-2016) of the investigations in 2014 and 2017 respectively. Drought spells emerged as the most experienced stimuli, followed by strong winds with median occurrences of three and two respectively. Our findings concur with Maponya and Mpandeli (2012) in Limpopo province and are also consistent with the results of Roco et al. (2016) who also indicated that most of their Chilean farmer respondents perceived that drought has become more frequent.

Table 1 Number of climate variability-related occurrences experienced by respondents in different time periods

\begin{tabular}{|c|c|c|c|c|c|c|c|c|c|}
\hline \multirow{2}{*}{$\begin{array}{l}\text { Disaster } \\
\text { type }\end{array}$} & \multicolumn{4}{|c|}{$2003-2013(\mathrm{~N}=194)$} & \multirow{2}{*}{$\begin{array}{l}\text { Disaster } \\
\text { type }\end{array}$} & \multicolumn{4}{|c|}{$2006-2016(\mathrm{~N}=322)$} \\
\hline & $\begin{array}{l}\mathrm{Mi} \\
\mathrm{n}\end{array}$ & Max & $\begin{array}{l}\text { Media } \\
\mathrm{n}\end{array}$ & $\begin{array}{l}\text { Skewnes } \\
\mathrm{s}\end{array}$ & & $\begin{array}{l}\mathrm{Mi} \\
\mathrm{n}\end{array}$ & $\operatorname{Max}$ & $\begin{array}{l}\text { Media } \\
\mathrm{n}\end{array}$ & $\begin{array}{l}\text { Skewnes } \\
\text { s }\end{array}$ \\
\hline $\begin{array}{l}\text { Strong wind } \\
(\mathrm{n}=80)\end{array}$ & 1 & 10 & 2.00 & 1.482 & $\begin{array}{l}\text { Strong wind } \\
(\mathrm{n}=98)\end{array}$ & 1 & 10 & 2.00 & 1.196 \\
\hline $\begin{array}{l}\text { Hailstorm } \\
(\mathrm{n}=89)\end{array}$ & 1 & 11 & 1.00 & 3.506 & $\begin{array}{l}\text { Hailstorm } \\
(\mathrm{n}=71)\end{array}$ & 1 & 6 & 1.00 & 2.543 \\
\hline $\begin{array}{l}\text { Flood } \\
(\mathrm{n}=40)\end{array}$ & 1 & 11 & 1.00 & 2.374 & $\begin{array}{l}\text { Flood } \\
(\mathrm{n}=41)\end{array}$ & 1 & 2 & 1.00 & 1.407 \\
\hline $\begin{array}{l}\text { Drought } \\
(\mathrm{n}=148)\end{array}$ & 1 & 11 & 3.00 & 1.424 & $\begin{array}{l}\text { Drought } \\
(\mathrm{n}=316)\end{array}$ & 1 & 19 & 3.00 & 3.422 \\
\hline
\end{tabular}

3.1.2 Respondents' views on trends in climate variability

It has been pointed out that over the last ten years from 2001 to 2010, global temperatures have averaged $0.46^{\circ} \mathrm{C}$ above the $1961-1990$ average, and are the highest ever recorded for a 10 -year period since the beginning of instrumental climate records (Maponya \& Mpandeli, 2012).

Respondents' views on trends in climate variability have been investigated by other scholars such as Roco et al. (2016) in Chile, Mertz, Cheikh-Mbow, Reenberg \& Diouf (2009) in Senegal and Gbetibouo, (2009) in South Africa. Such investigations are important because of the relationships between perceptions and behaviour, such as the adaptation strategies employed by producers (Roco et al., 2016; Mertz et al., 2009).

Respondents' views on trends in climate variability (Table 2) suggest that respondents in our study are aware of the reality of climate variability. 
Table 2 Respondents' views on trends in climate variability

\begin{tabular}{|c|c|c|c|}
\hline \multirow{3}{*}{$\begin{array}{l}\text { Trends in climate } \\
\text { variability } \\
\text { Temperature } \\
(\mathrm{N}=322)\end{array}$} & \multicolumn{3}{|c|}{ Period of investigation and respondents' (\%) experiences } \\
\hline & \multirow{2}{*}{$\begin{array}{l}\begin{array}{l}\text { 2006-2016 } \\
(2017)\end{array} \\
\begin{array}{l}\text { Respondents } \\
(\%)\end{array}\end{array}$} & \multicolumn{2}{|l|}{ 2003-2013(2014) } \\
\hline & & $\begin{array}{l}\text { Temperature } \\
\mathrm{N}=184\end{array}$ & $\begin{array}{l}\text { Respondents } \\
(\%)\end{array}$ \\
\hline More cooler periods & 6 & More cooler periods & 3 \\
\hline No Change & 1 & No Change & 3 \\
\hline More hotter periods & 93 & More hotter periods & 94 \\
\hline $\begin{array}{l}\text { Rainfall: Timing } \\
(\mathrm{N}=321)\end{array}$ & & $\begin{array}{ll}\text { Rainfall: } & \text { Timing } \\
(\mathrm{N}=193) & \end{array}$ & \\
\hline Generally too early & 13 & Generally too early & 34 \\
\hline No Change & 1 & No Change & 2 \\
\hline Generally too late & 86 & Generally too late & 64 \\
\hline $\begin{array}{l}\text { Rainfall: Intensity } \\
(\mathrm{N}=322)\end{array}$ & & $\begin{array}{l}\text { Rainfall: Intensity } \\
(\mathrm{N}=193)\end{array}$ & \\
\hline Rains a lot in a few months & 50 & Rains a lot in a few months & 75 \\
\hline No change & 1 & No change & - \\
\hline $\begin{array}{l}\text { Fairly distributed over } \\
\text { rainfall season }\end{array}$ & 49 & $\begin{array}{l}\text { Fairly distributed over } \\
\text { rainfall season }\end{array}$ & 25 \\
\hline
\end{tabular}

The findings show a consistency across the different time periods in all municipalities investigated. Most respondents (93\%) and (94\%) in 2017 and 2014 studies respectively, indicated experiencing more hotter periods in the years they could remember. Similarly, $80 \%$ or more and slightly over $60 \%$ respondents in both 2017 and 2014 study periods across all municipalities said the rains came generally too late for the planting respectively. Furthermore, half of the respondents in the 2017 survey and over $70 \%$ in the 2014 study indicated it rained a lot within a shorter period of time. These temperature and rainfall scenarios of course, have negative effects on crop production. Our findings mirror those of Roco et al. (2016) in Chile and Gbetibouo (2009) in the Limpopo basin of South Africa, where most farmers recognized that temperatures have increased, and rainfall on the other hand, has decreased or exhibit large inter-annual variability.

\subsubsection{Sensitivity of respondents' production to climate variability disasters}

Sensitivity was defined for this assessment as the degree to which a system is affected, either adversely or beneficially, by climate-related stimuli (Inter-Governmental Panel on Climate Change 2001). Farmers' perceptions of how they were affected by climate variability-related stimuli were assessed and the findings are presented in Table 3. 
Table 3 Perceived climate disaster-type causing crop damage and killing livestock

\begin{tabular}{|c|c|c|}
\hline $\begin{array}{l}\text { Climate disaster-type } \\
\text { causing crop damage }\end{array}$ & $\begin{array}{l}\text { 2003-2013 (2014) } \\
\text { Respondents }(\%) \mathrm{N}=98\end{array}$ & $\begin{array}{l}2006-2016(2017) \\
\text { Respondents }(\%) \mathrm{N}=303\end{array}$ \\
\hline Drought & 88.8 & 97.4 \\
\hline Flood & 8.2 & 0.7 \\
\hline Strong winds & 2.0 & 1.3 \\
\hline Hailstorm & 1.0 & 0.3 \\
\hline $\begin{array}{l}\text { Climate disaster-type } \\
\text { killing livestock }\end{array}$ & $\begin{array}{l}2003-2013(2014) \\
\text { Respondents }(\%) \mathrm{N}=104\end{array}$ & $\begin{array}{l}\text { 2006-2016 (2017) } \\
\text { Respondents }(\%) \mathrm{N}=103\end{array}$ \\
\hline Drought & 85.6 & 96.1 \\
\hline Floods & 7.7 & 1.0 \\
\hline Strong winds & 1.0 & 1.9 \\
\hline Hailstorm & 2.9 & 1.0 \\
\hline Lightning & 1.0 & 1.0 \\
\hline Landslides & 1.9 & - \\
\hline
\end{tabular}

The findings show that across time lines in all municipalities investigated, an overwhelming majority of respondents mentioned drought as the major cause of damage to their crops. Even though they were crop farmers, the majority of respondents, also indicated that their livestock died as a result of drought. Furthermore, across time lines and in all municipalities except in Giyani, most respondents lost between 1-10 animals; this was more devastating to respondents in Tzaneen where all respondents were severely affected (Table 4).

Production techniques may be as important as production technologies in climate change adaptation. One such technique stands out in particular: conservation or reduced tillage agriculture (Choudhary, Ghasal, Kumar, Yadav, Singh, Meena \& Jaideep, 2016).

Table 4 Number of livestock lost across time and municipalities

\begin{tabular}{|c|c|c|}
\hline $\begin{array}{l}\text { Number of } \\
\text { livestock lost }\end{array}$ & $\begin{array}{l}2017 \\
\% \text { of respondents per } \\
\text { municipality }(\mathrm{N}=104)\end{array}$ & $\begin{array}{l}2014 \\
\% \text { of respondents per } \\
\text { municipality }(\mathrm{N}=67)\end{array}$ \\
\hline $1-10$ & $\begin{array}{l}\text { Maruleng (88); } n=15 \\
\text { Tzaneen (100); } n=18 \\
\text { Giyani (27); } n=24 \\
\text { Phalaborwa (87); } n=33\end{array}$ & $\begin{array}{l}\text { Blouberg (78);n=14 } \\
\text { Aganang (94);n=16 } \\
\text { Fetakgomo (93);n=14 } \\
\text { Makhuduthamaga (77); } n=13\end{array}$ \\
\hline $11-20$ & $\begin{array}{l}\text { Maruleng }(12) ; \mathrm{n}=2 \\
\text { Tzaneen }(0) ; \mathrm{n}=0 \\
\text { Giyani }(13) ; \mathrm{n}=4 \\
\text { Phalaborwa }(13) ; \mathrm{n}=5\end{array}$ & $\begin{array}{l}\text { Blouberb (11);n=2 } \\
\text { Aganang (6);n=1 } \\
\text { Fetakgomo (7);n=1 } \\
\text { Makhuduthamaga (24);n=4 }\end{array}$ \\
\hline $21-30$ & $\begin{array}{l}\text { Maruleng }(0) ; \mathrm{n}=0 \\
\text { Tzaneen }(0) ; \mathrm{n}=0 \\
\text { Giyani }(3) ; \mathrm{n}=1 \\
\text { Phalaborwa }(0) ; \mathrm{n}=0\end{array}$ & $\begin{array}{l}\text { Blouberb }(6) ; n=1 \\
\text { Aganang }(0) ; n=0 \\
\text { Fetakgomo }(0) ; n=0 \\
\text { Makhuduthamaga }(0) ; n=0\end{array}$ \\
\hline 31 or more & $\begin{array}{l}\text { Maruleng }(0) ; \mathrm{n}=0 \\
\text { Tzaneen }(0) ; \mathrm{n}=0 \\
\text { Giyani }(7) ; \mathrm{n}=2 \\
\text { Phalaborwa }(0) ; \mathrm{n}=0\end{array}$ & $\begin{array}{l}\text { Blouberb }(6) ; n=1 \\
\text { Aganang }(0) ; n=0 \\
\text { Fetakgomo }(0) ; n=0 \\
\text { Makhuduthamaga }(0) ; n=0\end{array}$ \\
\hline
\end{tabular}


respondents' awareness of the reality of variability in the climate, they were then asked to mention the measures they had been implementing in the last five to ten years to reduce the negative impacts of this phenomenon on their crop production. Their responses are presented in Tables 5 and 6. Most public extension service recipients compared to non-recipients in the 2017 study reported the use of both conservation agricultural practices (CA) and technological improvements such as irrigation, application of fertilizers and pesticides. The conservation agricultural practices used were crop rotation/inter-cropping/mixed cropping ( $\mathrm{n}=87 ; 69 \%)$, soil mulching $(\mathrm{n}=86 ; 62 \%)$, soil ripping $(\mathrm{n}=85 ; 39 \%)$, no-till/direct seeding $(\mathrm{n}=85 ; 39 \%)$ and cover cropping $(\mathrm{n}=86 ; 71 \%)$. In the 2014 study however, soil conservation practices including crop production practices were used by most farmers in both farmer groups (extension service recipients $(n=69 ; 75 \%)$ and non-recipients $(n=118 ; 67 \%)$. Similar to the situation in the 2017 study, more extension recipients compared to non-recipients in the 2014 study, also used technological improvements such as irrigation, application of fertilizers and pesticides. The use of conservation agricultural practices and technological improvements by farmers in the two study periods suggests that farmers believe in the efficacy of these climate variability adaptation strategies to improve crop yields. This is significant in the sense that conservation agricultural practices have been found to increase maize yields without irrigation (Knowler \& Bradshaw, 2007; Boateng, 2011; Marongwe, Kwazira, Jenrich, Thierfelder, Kassam \& Friedrich, 2011).

Table 5 Crop production adaptation strategies used by respondents (2006-2016) 2017

\begin{tabular}{|l|l|l|l|l|}
\hline \multirow{2}{*}{ Adaption strategy } & \multicolumn{2}{l}{$\begin{array}{l}\text { Recipients of Extension } \\
\text { Services }\end{array}$} & \multicolumn{2}{l}{$\begin{array}{l}\text { Non-Recipients } \\
\text { Extension Service }\end{array}$} \\
\cline { 2 - 5 } & Respondent & Frequency & Respondent & Frequency \\
\hline Early or late planting & 87 & $72(83)$ & 232 & $18(08)$ \\
\hline Correct seeding rate/weeding times & 88 & $67(76)$ & 232 & $30(13)$ \\
\hline $\begin{array}{l}\text { Conservation agriculture: crop rotation } \\
\text { or mixed cropping or inter-copping }\end{array}$ & 87 & $60(69)$ & 232 & $06(03)$ \\
\hline Conservation agriculture: mulching & 86 & $53(62)$ & - & - \\
\hline Conservation agriculture: soil ripping & 85 & $31(37)$ & - & - \\
\hline $\begin{array}{l}\text { Conservation agriculture: no till/direct } \\
\text { seeding }\end{array}$ & 85 & $33(39)$ & - & - \\
\hline Conservation agriculture: cover crop & 86 & $62(71)$ & - & - \\
\hline Use of drought-resistant varieties & 86 & $45(62)$ & 232 & $01(0.4)$ \\
\hline Use of wetlands & 84 & $26(31$ & - & - \\
\hline Application of fertilizer/manure & 88 & $68(77)$ & 232 & $31(13)$ \\
\hline Water harvesting & - & - & - & - \\
\hline Use of irrigation & 88 & $24(27)$ & 232 & $2(1)$ \\
\hline Plant early or late maturing varieties & 87 & $54(62)$ & - & - \\
\hline Apply pesticide & 88 & $51(59)$ & - & - \\
\hline Do nothing & - & - & 232 & $121(52)$ \\
\hline
\end{tabular}

Numbers in brackets are percentages 
Table 6 Crop production adaptation strategies used by respondents 2003-2013 (2014)

\begin{tabular}{|l|l|l|l|l|}
\hline Strategy & \multicolumn{2}{l|}{$\begin{array}{l}\text { Recipients of Extension } \\
\text { Services }\end{array}$} & $\begin{array}{l}\text { Non-Recipients } \\
\text { Extension Service }\end{array}$ \\
\hline & Respondent & Frequency & Respondent & Frequency \\
\hline $\begin{array}{l}\text { Early or late planting; early or late } \\
\text { maturing varieties }\end{array}$ & 69 & $48(70)$ & 119 & $26(22)$ \\
\hline Correct seeding rate/weeding & 69 & $23(33)$ & 119 & $39(33)$ \\
\hline Conservation agriculture & 69 & $52(75)$ & 118 & $79(67)$ \\
\hline Use of drought-resistant varieties & 68 & $39(57)$ & 119 & $21(18)$ \\
\hline Use of wetlands & 69 & $15(22)$ & 118 & $2(2)$ \\
\hline Application of fertilizer/manure & 69 & $45(65)$ & 119 & $31(26)$ \\
\hline Water harvesting & 68 & $1(2)$ & 119 & $9(8)$ \\
\hline Use of irrigation & 69 & $15(22)$ & 119 & $2(2)$ \\
\hline
\end{tabular}

Numbers in brackets are percentages; CA type used by respondents (crop rotation/mixed cropping; mulchinhg

The use of adaptation strategies by farmers may be constrained by a lack of resources. A study in Zimbabwe by Kwami, Chigonda, and Rusena (2018) indicated that farmers in Chingechuru adopted various adaptation strategies to climate change such as the growing of drought resistant crop varieties, growing of early maturing varieties, staggering of planting dates and improved grain storage among other adaptation strategies. The authors, however, mentioned that various constraints including lack of resources and ineffective extension services made it impossible for the majority of the farmers in the study area to adopt the various climate change adaptation strategies.

\subsection{CROP PRODUCTIVITY OF RECIPIENTS AND NON-RECIPIENTS OF PUBLIC EXTENSION FARM MANAGEMENT INFORMATION INCLUDING CLIMATE VARIABILITY}

Despite methodological challenges such as biases resulting from endogenous placement and omitted variable bias, the evidence on the impact of extension services on farmers' productivity and technological adoption is generally positive (Cerdán-Infantes, Maffioli \& Ubfal, n.d). Orivel (1983) in his review of the literature on the impact of agricultural extension also shows that receiving extension information improves farm productivity despite methodological weaknesses.

The research question about how the farmers' crop productivity (grain yield in tons/ha) differed across time and in various municipalities investigated and the associated research hypothesis that subsistence dryland farmers' grain productivity does not differ across time and in various municipalities of Limpopo province was also tested. In light of this research question and hypothesis, crop productivity (yields in terms of t/ha) of respondents was assessed for respondents who received or did not receive public extension farm management information including climate variability. The findings across time and aggregated for all the different local municipalities are summarized in Tables 7-10. The results show that in all cases, the yields of recipients of extension farm management information including climate variability were better than for non-recipients. 
Table 7 Percentage distribution of respondents' crop yields according to use of Extension (2017)

\begin{tabular}{|l|l|l|}
\hline \multirow{2}{*}{ Yield (t/ha) } & Use of Public Extension (visits) \\
\cline { 2 - 3 } & Used (\%) (N= 88) & Did not use (\%) (N=234) \\
\hline Less than 1 & 96.0 & 98.0 \\
\hline $1-2.99$ & 3.0 & 1.0 \\
\hline $3-4.99$ & 1.0 & 1.0 \\
\hline
\end{tabular}

Table 8 Mean yield (t/ha) differences according to extension support (2017)

\begin{tabular}{|l|l|l|l|}
\hline $\begin{array}{l}\text { Use of public extension for farm management } \\
\text { information }\end{array}$ & $\begin{array}{l}\text { Number of } \\
\text { respondents }\end{array}$ & Mean & Std. Dev. \\
\hline $\begin{array}{l}\text { Received farm management information including } \\
\text { climate variability information }\end{array}$ & 88 & .2152 & .44782 \\
\hline $\begin{array}{l}\text { Did not receive farm management information } \\
\text { including climate variability information }\end{array}$ & 234 & .1146 & .48675 \\
\hline
\end{tabular}

Table 9 Percentage distribution of respondents' crop yields according to use of Extension (2014)

\begin{tabular}{|l|l|l|}
\hline \multirow{2}{*}{ Yield (ton/ha) } & Use of Public Extension (visits) \\
\cline { 2 - 3 } & Used $(\%)(\mathrm{N}=88)$ & Did not use $(\%)(\mathrm{N}=234)$ \\
\hline Less than 1 & 66.0 & 79.0 \\
\hline $1-2.99$ & 32.0 & 20.0 \\
\hline $3-4.99$ & 1.5 & 0.9 \\
\hline
\end{tabular}

Table 10 Mean yield (ton/ha) differences according to extension support (2014)

\begin{tabular}{|l|l|l|}
\hline \multirow{2}{*}{ Yield (ton/ha) } & \multicolumn{2}{|l|}{ Use of Public Extension (visits) } \\
\cline { 2 - 3 } & Used (\%) (N=68) & Did not use (\%) (N=113) \\
\hline Less than 1 & 66.0 & 79.0 \\
\hline $1-2.99$ & 32.0 & 20.0 \\
\hline $3-4.99$ & 1.5 & 0.9 \\
\hline
\end{tabular}

\subsubsection{Results for Independent-samples t-test}

An independent samples t-test was conducted to test the study hypothesis to compare the statistical significance of crop yields for recipients and non-recipients of public extension farm management information including climate variability across time and municipalities. The results indicated that in the 2017 study, there was no significant difference in yields for extension recipients and non-recipients $(\mathrm{M}=.2152, \mathrm{SD}=.44782)$ and non-recipients $(\mathrm{M}=.1446$. $\mathrm{SD}=.48675 ; \mathrm{t}(169.024)=1.231, \mathrm{p}=.220$ (two-tailed). The Levene's test of assumed equal variances was not violated $(\mathrm{p}=.311)$. The 2014 study on the other hand, showed a significant difference in the yields for those who received extension information/service $(\mathrm{M}=0.9058, \mathrm{SD}=$ $0.81725)$ and those who did not $(\mathrm{M}=0.5482, \mathrm{SD}=0.60696) ; \mathrm{t}(113.378)=3.147, \mathrm{p}=.002$ (twotailed). This $\mathrm{p}$-value is based on equal variances not assumed containing an adjusted t-test that corrects for a lack of homogeneity in the data. The magnitude of the difference in the mean yields (mean difference $=.36,95 \mathrm{CI}$. 13 to .58 ) was small, though (eta squared $=.05)$ (Pallant 2007). Betz (2009) made a similar finding in Uganda of positive and significant relationship between agricultural extension visits and value of output for subsistence/small farmers even though the magnitude of the coefficient on the extension variable was fairly small. Our findings 
of positive relationship between receiving extension and productivity, albeit, small, is thus supported by literature.

\section{CONCLUSIONS}

The similar findings across time (2014 and 2017) and aggregated for all the different local municipalities investigated regarding respondents' perceptions of climate variability, their views of influence of climate variability on crop and livestock production, their adaptation strategies and agricultural productivity suggest that we have data for evidence-based decision making regarding the type of support for these producers. The lack of almost no differences in grain yield aggregated for all municipalities among recipients and non-recipients of public extension farm management information including climate variability in the 2014 and 2017 studies seems to indicate that the extension support received by producers is not effective enough. These findings auger well for the development of strategies to improve the effectiveness of farm management information including climate variability delivered to this group of producers. This will help to improve producers' grain productivity and reduce the negative effects of climate variability on their crop productivity.

Key limitation of the findings is that the study focussed on the status quo regarding respondents' perceptions of climate variability, their views of influence of climate variability on crop and livestock production, their adaptation strategies and grain productivity based on whether or not they received public extension services. The findings should therefore, not be seen as respondents' predictions of their perceptions in relation to their adaption strategies and their grain productivity because that was not the intention of the study.

\section{ACKNOWLEDGEMENTS}

1. Department of Science and Technology and the National Research Foundation through the Risk and Vulnerability Science Centre at University of Limpopo for the financial support.

2. VLIR-IUC Programme at the University of Limpopo.

\section{REFERENCES}

AFFUL, D.B., OLUWATAYO, I.B., KYEI, K.A., AYISI, K. \& ZWANE, E.M. 2014. Climate variability and subsistence crop farmers' food security in Limpopo Province of South Africa: the role of public extension. (Unpublished), University of Limpopo, South Africa.

AFFUL, D.B. \& AYISI, K. 2017. Climate variability and subsistence crop farmers' food security in Limpopo Province of South Africa: the role of public extension. (Unpublished), University of Limpopo, South Africa.

ALTMAN, M., HART, T. \& JACOBS, P. 2009. Household food security status in South Africa. Agrekon. 48 (4): 345.360.

ARTS, J.W.C., FRAMBACH, R.T. \& BIJMOLT, T.H.A. 2011. Generalizations on consumer innovation adoption: A meta-analysis on drivers of intention and behaviour. Available from http://ssrn.com/abstract=2001934.

ASSAN, R. \& NHEMACHENA, C. 2008. Determinants of African farmers' strategies for adapting to climate change: Multinomial choice analysis. AfJARE. 2 (1): 83-104. 
BETZ, M. 2009. The effectiveness of agricultural extension with respect to farm size: The case of Uganda. Selected Paper prepared for presentation at the Agricultural \& Applied Economics Association 2009, AAEA \& ACCI Joint Annual Meeting, Milwaukee, Wisconsin, July, 26-29, 2009.

BOATENG, D.O. 2011. Manual for maize production, Bunso Cocoa College, Bunsu. Available from:

https://www.google.co.za/search?q=Improved+rice+variety+adoption+and+its+effect s+on+farmers\%E2\%80\%99+output+in+Ghana\&ie=utf-8\&oe=utf-

$\underline{8 \& a q=t \& r l s=o r g . m o z i l l a: e n-U S: o f f i c i a l \& c l i e n t=\text { firefox- }}$ a\&channel=np\&source $=$ hp\&gfe $\_r d=c r \& e i=7$ ottVN3KJ42p8wehm4CABw\#rls=org.m ozilla:en-

US:official\&channel=np\&q=Boateng+DO+2011.+Manual+for+maize+production

BRONDIZIO, E.S. \& MORAN, E.F. 2008. Human dimensions of climate change: the vulnerability of small farmers in the Amazon. Retrieved from http://www.ncbi.nlm.nih.gov/pmc/articles/PMC2374891/

CERDÁN-INFANTES, P., MAFFIOLI, A. \& UBFA, D. n.d. The Impact of Agricultural Extension Services: The Case of Grape Production in Argentina. Available from https://scholar.google.co.za/scholar?hl=en\&as_sdt=0\%2C5\&q=The+Impact+of+Agri cultural+Extension+Services $\% 3 \mathrm{~A}+\mathrm{The}+\mathrm{Case}+\mathrm{of}+\mathrm{Grape}+$ Production+in+Argentina\& $\underline{b t n G}=$

CHOUDHARY, M., GHASAL, P.C., KUMAR, S., YADAV, R.P., SINGH, S., MEENA, V.S. \& JAIDEEP, K.B. 2016. Conservation Agriculture and Climate Change: An Overview. Available

from https://www.researchgate.net/publication/311418457_Conservation_Agriculture_and Climate_Change_An_Overview

CLEMENTS, R., HAGGAR, J., QUEZADA, A. \& TORRES, J. 2011. Technologies for Climate Change Adaptation - Agriculture Sector. Available from https://orbit.dtu.dk/files/5706575/Technologies_for_Climate_Change_Adaptation_Ag riculture_sector.pdf

DAZE, A., AMBROSE K., EHRHART, C. 2009. Climate Vulnerability and Capacity Analysis (Handbook). London: CARE International, Available from https://scholar.google.co.za/scholar?hl=en\&as_sdt=0\%2C5\&q=DAZE+A\%2C+AMB ROSE+K\%2C+EHRHART+C+2009.+Climate+Vulnerability+and+Capacity+Analys is\&btnG

DEPARTMENT OF AGRICULTURE. 2002, Integrated Food Security for South Africa. Department of Agriculture, Pretoria, South Africa.

DEPARTMENT FOR INTERNATIONAL DEVELOPMENT. 1999. Sustainable Livelihoods Guidance Sheets. Department for International Development, London, UK.

D' HAESE M, vAN ROOYEN, J., VINK, N. \& KIRSTEN, J. 2011. Food Security in Limpopo Province of South Africa. Available from http://scholar.sun.ac.za/handle/10019.1/39964

EGBE, C.A., YARO, M.A., OKON, A. E., ISONG, F.E. 2014. Rural Peoples' Perception to Climate Variability/Change in Cross River State-Nigeria. J. Sustain. Dev. 7 (2): 25-36.

FOOD AND AGRICULTURE ORGANIZATION. 2004. Socio-economic Analysis and Policy Implications of the Roles of Agriculture in Developing Countries, Summary Report, Roles of Agriculture Project, Food and Agriculture Organization, Rome, Italy. Available from https://slideplayer.com/slide/6375267/

GBETIBOUO, G.A. \& RINGLER, C. 2009. Mapping South African Farming Sector Vulnerability to Climate Change and Variability. A Subnational Assessment. IFPRI 
Discussion Paper 00885, International Food Policy Research Institute (IFPRI), Washington, DC.

GBETIBOUO, G.A. 2009. Understanding farmers' perceptions and adaptations to climate change and variability: The case of the Limpopo Basin, South Africa. Available from https://books.google.co.za/books?id=WHvzHG9g6AC\&printsec $=$ frontcover\#v $=$ onepage \&q \& $\mathrm{f}=$ false

GREGORY, P.J., INGRAM, S.I., BRKLACICH, M. 2005. Climate change and food security. Philos. Trans. Royal Soc. B., 360: 2139-2148.

INTER-GOVERNMENTAL PANEL ON CLIMATE CHAANGE. 2001. Climate change: Impacts, Adaptation and Vulnerability, Summary for Policymakers, WMO. Available from $\quad$ http://www.ipcc.ch/pdf/climate-changes-2001/impact-adaptationvulnerability/impact-spm-en.pdf

KHAPAYI, M.I, \& CELLIERS P.R. 2016. Factors limiting and preventing emerging farmers to progress to commercial agricultural farming in the King William's Town area of the Eastern Cape Province, South Africa. S. Afr. Jnl. Agric. Ext., 44 (1): 25-44.

KNOWLER, D. \& BRADSHAW, B. (2007). Farmers' adoption of conservation agriculture: A review and synthesis of recent research. Food Policy, 32: 25-48.

KWAMI, T., CHIGONDA, T. \& RUSENA, T. 2018. Climate change adaptation by Farmers in Chingechuru Ward, Mberengwa District, Zimbabwe. Eur. J. Soc. Sci Stud. 3 (2): 158-167.

MAPONYA, P. \& MPANDELI, S. 2012. Climate Change and Agricultural Production in South Africa: Impacts and Adaptation options. J. Agric. Sci, 4 (10): 48-60.

MARONGWE, L.S., KWAZIRA, K., JENRICH, M., THIERFELDER, C.K., KASSAM, A \& FRIEDRICH, T., 2011. An African success: The case of conservation agriculture in Zimbabwe. Int. J. Agr. Sustain. 9 (1): 153-161.

MARCOTT, S.A, SHAKUN, J.D, CLARK, P.U. \& MIX, A.C. 2013. A Reconstruction of Regional and Global Temperature for the Past 11,300 Years. Science, 339: 1198-1201 Available from https://www2.bc.edu/jeremyshakun/Marcott\%20et\%20al.,\%202013,\%20Science.pdf

MBEREGO, S., SANGA-NGOIE K., 2014. Using locally captured climatic information for guiding local-level agriculturalists in Africa: a case study of Makonde district in Zimbabwe. J. Land Use Sci., 9 (2): 178-194.

MERTZ, O., CHEIKH-MBOW, C., REENBERG, A \& DIOUF, A. 2009. Farmers' Perceptions of Climate Change and Agricultural Adaptation Strategies in Rural Sahel. Environ. Manage. 43: 804-816.

NELSON, R., KOKIC, P., CRIMP, S., MARTIN, P., MEINKE, H., HOWDEN, S.M., P. de VOIL, U. \& NIDUMOLU. 2010b. The Vulnerability of Australian Rural Communities to Climate Variability and Change: Part II - Integrating Impacts with Adaptive Capacity. Environ. Sci. Policy, 13: 18 - 27.

MINAE, S., BAKER, D., DIXON, J. n.d. Status of Farm Data Systems and Farmer Decision. Available from http://www.fao.org/tempref/upload/Agrippa/628_en.pdf

ORIVEL, F. 1983. The Impact of Agricultural Extension Services: A review of the Literature In Perraton et al. (Eds.), Basic Education and Agricultural Extension- Costs, Effects, Alternatives. World Bank staff working paper 564, Washington DC.

PALLANT, J. 2007. SPSS Survival Manual: A Step-by-Step Guide to Data Analysis Using SPSS. Version 17, 3rd ed. McGraw-Hill: Berkshire.

REASON, C.J.C., HACHIGONTA, S., PHALADI, R.F.R. 2005. Inter-annual Variability in Rainy Season Characteristics over the Limpopo Region of Southern Africa. Available From: www.interscience.wiley.com 
ROCO, L, ENGLER, A, BRAVO-URETA, B.E. \& JARA-ROJAS, R. 2016. Farmers' perception of climate change in Mediterranean Chile. Reg. Environ. Chang. 15: 867879.

STATISTICS SOUTH AFRICA (STATS SA). 2016. Community Survey 2016: Statistical release. Available from: www.statssa.gov.za

TORNATZKY, LOUIS G., KATHERINE J. \& KLEIN. 1982. Innovation Characteristics and Innovation Adoption-Implementation: A Meta-Analysis of Findings. Trans. Eng. Manag 29 (1): 28-45.

TURPIE, J. \& VISSER, M., 2012. The Impact of Climate Change on South Africa's Rural Areas. Available from http://www.efdinitiative.org/centers/south-africa/newspress/news-chive/2009/climate-impacts-on-south-africa2019s-rural-areas

VINCENT, K. \& CULL, T. 2010. A Household Social Vulnerability Index (HSVI) for Evaluating Adaptation Projects in Developing Countries'. Paper presented in PEGNet Conference 2010, Policies to Foster and Sustain Equitable Development in Times of Crises. Midrand, South Africa. 